\title{
Historiosophical Aspects of the World Civilization Transformations and Development of the Phenomenon of Sport and Tourism
}

\author{
Mirosław Mylik \\ Bogdan Jański Higher School, Warsaw, Poland
}

\begin{abstract}
The article concerns the problems of civilization transformations of mankind, starting from the Great French Revolution period of 1789 until almost to the end of the 20th century. These transformations are shown not only in historical aspects, but also in philosophical light of some historical necessities which had a huge impact for both the past and the present times and surely also for future human generations. Generally on this basis, the author of this article tries to get to know the origin of rise, the most important causes, and the final effects of the most important civilization transformations of the past two centuries. Hence, first the phenomenon of creation and sudden civilizational leap of all the world transformations was characterized. Then, these transformations were investigated while paying special attention to genesis and development of European scientific positivism, whose origins date back to the 18th century and continue almost uninterruptedly until the end of the 20th century. At that time, most of the European scholars, who studied a rapidly changing world, went from questions like "why" to answers "what is" the whole reality that surrounds us. One of the many examples of this kind of transformation of the scholars' attitude is the fact of modern revival and development of the phenomenon of sport and tourism in the worldwide edition. This phenomenon of the sport renaissance and the development of international tourism is one of the many aspects of the global historical process of recent centuries, the essence of which was explored in this article.
\end{abstract}

Keywords: philosophy of history, transformation, civilization, sport, tourism

\section{The Phenomenon of Origin and Development of World Civilization Transformations}

Political, social, scientific, technical, economical, cultural, moral, and religious changes, which came up in the second half of the 18th century and evolved incredibly dynamically through the whole 19th century and lasted almost incessantly until the end of the 20th century, brought to humanity not only the commonly known bywords of the Great French Revolution: freedom, equality, and brotherhood, but also the scientific and technical revolution, unprecedented in the human history, which only in the last two centuries brought much more than in the previous centuries new scientific truths, technological inventions, expeditions, geographical discoveries, etc., which, in turn, brought the unfinished history of great industrial revolution of modern technologies, industrial corporations, data networks, mechanisms of the market, globalization processes, economical unions, military alliances, space programs and infinitely many more, impossible to mention in one

Mirosław Mylik, Ph.D., Department of Social Sciences, Bogdan Jański Higher School. Email: mmylik@op.pl. 
work, civilization achievement of humanity, which we constantly use, convert, and improve. We even foresee a new great cosmic revolution, unknown to us fully from today's point of time, of human development in the 21 st and following centuries. ${ }^{1}$

The Great French Revolution of 1789 was not only "great" in name, as with the earlier July Revolution in France, the August Revolution in Belgium, and all revolutions of 1848 and 1849 and the famous Commune in Paris up to three Russian revolutions of the 20th century, to say nothing about later effects of the First and Second World Wars went far not only in Europe, but on the whole world to decay of monarchy and feudal order for inception of parliamentarianism and capitalism and, what is linked, to the birth of new social classes, structures, and relations, mainly between the so-called bourgeoisie and proletariat. $^{2}$

To this creation, development and the most important preservation of new, parliamentary capitalistic order started at the end of the 18th century, much contributed the 19th century. Not without the reason it was called "the century of steam and electricity", as its unprecedented so far in human history scientific-technical achievements and great geographical discoveries showed totally new directions of civilization development of our planet. ${ }^{3}$ Thanks to the "steam and electricity" invented prototypes of steam machines more and more

\footnotetext{
${ }^{1}$ Famous American futurologist, Alvin Toffler called those changes, started at the end of the 18th century and continued in the 19th century until the first half of the 20th century, "the industrial second wave", which, after the "first wave" of agricultural multi-centennial change of primitive people into rural societies, changes almost instantly in the second half of the 20th century into the "third wave" of postindustrial civilization of all mankind. All his three changes were exhibited in his book, entitled The Third Wave (Toffler, 1980). Another well-known American scientist, Francis Fukuyama, followed his steps. He called those civilization changes a great shock, because this transition from the industrial to informational age is for the mankind as important as it used to be the transition from the heading to agriculture of later: the Industrial Revolution. Those words are covered in Fukuyama's (2000) book entitled The Great Disruption: Human Nature and the Reconstitution of Social Order and his book entitled Trust: The Social Virtues and the Creation of Prosperity (1997). All Fukuyama's books above and Toffler's works are interesting and important in the western world philosophically social studies about the three most important human history transformations which happened in the world throughout all the centuries of the existence of our civilization and especially its last decades of the 20th century. In Poland, this topic is referred to by the last book of Maria Hirszowicz (2007), entitled Stad, ale dokad? Spoleczeństwo u progu nowej ery.

${ }^{2}$ Bibliography referring to universal history of 1789-1918 is so great, which as Ludwik Bazylow (1981) said: "No selection helps, it is completely unknown" (p. 975). That is the reason why a compound literature of this period may and should be divided into the so-called old and new. The older literature should be started from the translation from French, more than 800 pages book of Charles Seignobos (1900), entitled Dzieje polityczne Europy współczesnej. Rozwój stronnictw i form politycznych 1814-1899. This translation was edited and supplemented by the history of 1896-1895 by Jan Stecki. One year later, two volumes of Historia XIX stulecia: Dzieje polityki, literatury, sztuki, nauki, przemystu, i.t.p. Opracowane na podstawie najnowszych badań i objaśnione licznymi ilustracjami, edited by Dr Aleksander Ciechowski (Vols. 1-2, Warsaw 1901); Vol. 3 in turn Warsaw 1902. Texts of particular volumes were compiled by Dr A. Ciechowski, Dr Zygmunt Grudziński, Józef Tokarzewicz (Hodi), and Gabriel Tołwiński. In 1906, Historia nowoczesna 1788-1805 uzupetniona latopisem XIX stulecia. Finally in the twenties of the 20th century, a lot of Polish textbooks of universal history are edited mainly for teachers and studies of high school. It started a new age on Polish editorial market of works of universal history of latest times, including Polish modern history. This age exists until today.

3 This paper compares the work of the great American historian, Martin Malia (2006), entitled History's Locomotives: Revolutions and the Making of the Modern World. In this book, Malia (2006) proved that the most important causes of this that happens in modern world are "history's locomotives", which are chosen by him to be the most important moments in history. That is the reason why Malia not only described or analyzed historically as for example the process of the 15th century Hussite wars in the Czech Republic, religious wars in Germany in the 16th century, or revolutionary changes in England in the 16th century, but also showed its meaning in our times. For example, Great French Revolution according to Malia was the beginning of the end of the revolution age, which was finally closed by Great October Revolution in Russia. From among Polish authors distinguishes the most latest work of Andrzej Chwalba (2008), entitled Historia Powszechna. Wiek XIX, where the author shared in a new way a universal history of the world of 1789-1914 on two main parts, which are civilization and politics. Around these great issues he wrote his historical descriptions and concludes also interesting for us as well civilization changes and political events of the 19th century. Finally, see also not less innovative historical essay of Felipe Fernandez-Armesto (2000), entitled Civilizations: Culture, Ambition, and the Transformation of Nature, where the author, who permanently lived in England, tried to define and give the characteristic features of our civilization on the basis of his own vision of the history of civilization changes of humanity of the end of the 20th century. He understood this period generally as the beginning of the age of the world's globalization.
} 
modern type and of different kinds of adopting electrical devices could in time substitute less efficient hand work for much more effective mass production. Thanks to that, small, craftsmen workshops could be closed and turned into more modern, industrial factories. ${ }^{4}$

Because of that radically changed not only the work market, payment, and social relations, especially among employers and employees, but also worldwide intensified the supply and demand for the industrial products. Because of that trade ${ }^{5}$, transport and communication incredibly developed almost on the whole world at sea, river, land, and soon in the air.

It increased dramatically the quantity and quality of new means of transport, by first exploring, then implementing and finally popularizing first steamer, locomotive, automobile, and airplane. It caused an unfinished need for railway infrastructure, land engineering, or road logistics. New means and needs of land, railway, sea, river, and air transport called another epoch-making civilization need of humanity for historically new means of communication and unknown till now ways of communicating or popularizing, for example, telegraph, telephone, or photography; also improving known until now and using completely new computer equipment or communication technology. In other words, a completely new era appeared, "a great era of industry", which only by its economic potential created totally unknown possibilities of sea and inland navigation, railway, car routes, airlines, etc.. In the face of new industrial, trade, or transport needs, men had to learn the enterprise and how to become more professional managers and how to communicate in a modern way. This again enforced people to modernize already existing or create totally new products and information, logistic, marketing, consulting, legal, postal, banking, credit, financial, tourist, and insurance services, etc.. ${ }^{6}$

All those world changes given above, especially those of social and economical branch, would not be at all possible to realize without earlier mentioned politically-historical events or later caused scientific and technical revolution. It revolutionized the creation and development of the so-called "a great era of industry".

No wonder, then, that almost all from social thinkers from the end of the previous century, as rightly says modern American researcher, Francis Fukuyama - Ferdinand Tönnies, Henry Maine, Max Weber, Emile Durkheim, and Georg Simmel - devoted themselves to explaining this transformation (Fukuyama, 2000, p. 18).

\footnotetext{
4 The inventor of steam machine is believed to be James Watt (1736-1819), who in 1763 refined atmospheric steam engine built in 1705 by Thomas Newcomen (1663-1729). The invention of this piston steam engine allowed Nicolas Joseph Cugnot (1725-1804) in 1769 to construct and present the first world mechanical vehicle of steam drive which, after considerable modifications, started production in 1907 in Henry Ford's (1863-1947) workshops in Detroit, USA. The steam machine was also adopted in the first cotton mill in England in 1784 and 1803. Robert Fulton (1765-1815) built his first steam ship. In years of 1814-1825, George Stevenson (1781-1848) made his first steam locomotive. All those inventions and prototypes of machines much contributed to the inception and development of the so-called industrial revolution, which exists until today and its eventual end is not seen from our time perspective.

${ }^{5}$ Charles Louis de Montesquieu (1689-1755), in his work $O$ duchu praw from 1748, rightly noted that trade civilizes and mitigates barbaric customs as we daily see (Book 20, Chapter 1). Montesquieu took this idea from Samuel Ricard (1637-1717), whose words below from 1704 were quoted and popularized almost all the 18th century: "Trade gathers people because of its mutual mileage... Through trade people learn logic, honesty, manners, responsibility and temperance in speech and action. Seeing that cleverness and honesty is necessary to gain vogue, man avoids evil and at least his behavior expresses decency and solemnity, not to encourage to any reluctant judgment from present and future friends". This paper quotes the world esteemed German economist Albert Otto Hirschman (1982, p. 1465), Rival Interpretations of Market Society: Civilizing, Destructive, or Feeble. Finally, the ideas of Ricard and Montesquieu are similar about the role in meaning of world's trade spotted and used in Adam Smith's (1723-1790) classical economic theory, which seems modern us American philosopher Charles L. Griswold (1999) in his famous book on the West, entitled Adam Smith and the Virtues of Enlightenment.

${ }^{6}$ Enormous professional literature came into being which does not seem to have an end, when we take into account only new works of universal history, politics, economics, literature, art, science, etc., which came into existence. Doubtfulness arises as to whether it is possible to fully describe the history of transformation of human civilization in the 19th century.
} 
To that all meaningful and one would think endless historical events, radical social changes, enormous economical transformations, great scientific discoveries, quick technological progress, and more civilizational achievements of that time, which, as we said before, it is impossible to present not only in this paper, we should also add different expeditions, travel research, geographical discoveries, etc., which started to take place at the turn of the 15th and 16th centuries and increased in later centuries, including all unknown or almost unknown before lands, mountains, islands, seas, oceans, rivers, and even two polar poles. $^{7}$

In that extent, this paper does not mention on purpose Polish inventors, explorers, or travelers of that time, because the contribution they made in science, technology, or any other civilization discipline is not really great, as from times of Mikołaj Kopernik (1473-1543), there was nobody, who would be able to "hold the Sun and move the Earth" like him in general human consciousness. ${ }^{8}$ A different and controversial thing is if anyone at all from our or foreign scientists of that time would be not only inclined, but also able to make a discovery so great and crucial to gain a place of honor in the history of science, art, or culture and be announced by the future generations as a creator or a famous Copernican turn in the universal history of human science, culture, and civilization of the end of the 18th, 19th, or 20th centuries, not saying of the 21 st and next centuries of the existence of our civilization!?

That is the reason why most of Polish scientists of that time, and many our artists, creators of new disciplines of technology, art, or culture did not focus at that time on creating new ideas, discovering unknown scientific truths, searching for new technological solutions, or finding undiscovered geographical places. Still,

\footnotetext{
${ }^{7}$ Admittedly, the history of the oldest geographical discoveries dives into the ancient times, where Egyptian sailors made a legendary discovery of Punt lands (probably Somalia or southern coast of Arabic Sea) around 1500 BC. Phoenicians, Greeks, Carthaginians, and others sailed after them. Then still, the breakthrough date and the beginning of the so-called "age of great geographical discoveries" are believed to be 1415 when the Portuguese assaulted Ceuta. It is a port on the Mauritanian coast, which occurred to be a great base for further expansion in direction of Atlantic and the centre of the African continent. Another historical beginning of this age is definitely sailing around Africa through the Cape of Good Hope and getting to Madagascar by Bartłomiej Diaz (1450-1500) in 1488; finding America by Christopher Columbus (1451-1506) on October 12, 1492 and then the conquest of the American continent; trip of Vasco da Gama (1460-1524) along the new sea track to India in 1498 and the first sea travel around the world by Ferdinand Magellan (1480-1521) in the years of 1519-1522. The causes, process, and effects of these and following explorations and geographical discoveries are generally known and described not only in some scientific compilations about, generally speaking, the history of geographical discoveries, but also in some travel dairies, notes, logs, travel books, and other kinds of literature of travelers, writers, etc..

${ }^{8}$ Compare, for example, the encyclopaedian edition of Volume I, entitled Wielkiebiografie. Przywódcy, reformatorzy, myśliciele, Warsaw 2007, p. 792; Vol. II, Wielkie biografie. Pisarze, kompozytorzy, artyści, Warsaw 2007, p. 816; and Vol. III, Wielkiebiografie. Odkrywcy, wynalazcy, uczeni, Warsaw 2008, p. 768 (joint publication "Seria Wielkich Tematów"). All three volumes of this encyclopedia consist of, generally speaking, biographic passwords broaching life and work of men, who made a vital change in the history of the world by the development of science, civilization, and culture from the prehistoric times until modern times. The 3-volumed encyclopedia is also entirely enriched by interesting backup materials, in particular, volumes in the shape of description of literature, musical, artistic works, inventions object, theories, and also known quotations, rich pictures, drawings, maps, calendars, and indexes. Not surprisingly, the first two volumes were given a prestigious award "Edukacja XXI" during the 23rd national trade of educational books "Edukacja XXI", which took place in Warsaw in the category "encyclopedias, albums, dictionaries, lexicons". This award was established in 1994. It honors educational and cognitive values as well as an editorial level of books by Polish authors.

9 Although Immanuel Kant (1724-1804) declared "Copernican revolution" in philosophy in his work Krytyka czystego rozumu (Kant, 1787), because of which he gained a great place in the universal history of philosophy. However, it is still difficult to gain such general appreciation, even for famous Nobel laureates, to be recognized on upheaval in the science as great as the work of Copernicus.
} 
our Polish scientists took part in those activities as well. ${ }^{10}$ They focused rather on transferring foreign civilizational ideas to the Polish realities. In the times of lost independence, it was aimed first to keep the national identity, then to regain national independence, and finally to keep a permanent sovereignty by our country. Besides, any encyclopaedian scientific study or only dictionary historical index of Polish and foreign discoverers or inventors seems to be endless in the history of mathematics, chemistry, biology, astronomy, geography, physics ${ }^{11}$, medicine ${ }^{12}$, and many other different branches of new art, culture, and scientific disciplines.

\section{The Phenomenon of Origin and Development of the European Scientific Positivism}

We have to remember that behind that enormous quality and quantity of new scientific researches, technological inventions, explorations, geographical researches, etc., there is an incredible phenomenon of creation and quick development of new, the so-called "positive sciences", mainly natural and technological sciences and even in some extent theological sciences, for example, modern biblical archeology, natural Christian anthropology, or catholic Christian science. ${ }^{13}$

An incredible need of that time was not only the discovery of new scientific truths themselves, the search for epochal, technological inventions, or the discovery of unknown geographical areas. Not less important historical need occurred to be its practical use in human everyday life, by application within positive science,

\footnotetext{
${ }^{10}$ From among Polish scientists of that time, we should name a Nobelist in physics (1903) and chemistry (1911), Marie Skłodowska-Curie (1867-1934), who with her husband Pierre Curie (1859-1906) discovered two radioactive elements: polonium and radium. In that time, other two scientists became famous, Zygmunt Wróblewski (1845-1888) and Karol Olszewski (1846-1915), who succeeded in liquefying oxygen and nitrogen from air. Marian Smoluchowski (1872-1917) was another scientist who gained a success: He is believed to be one of the brightest Polish scientists of theoretical physics. Among Polish explorers, there is Stefan Szolc-Rogoziński (1861-1896), who with another Polish explorer Leopold Janikowski (1855-1942) and geologist Klemens Tomczek (1860-1884), made in the years of 1882-1883 an scientific expedition to Cameroon, where among others they explored the volcanic massif Cameroon, basin of the Mungo River, and they also discovered Elephant Lake and springs and upper stream of Rio del Rey. Similar geographical-scientific expeditions to many new places and unknown lands of Asia, Australia, New Zealand, Oceania, and America were taken, and even arctic expeditions to both poles were taken, which are risky at that time. In those arctic expeditions and polar explorations, Polish scientists became famous, too: Aleksander Czekanowski (1833-1876) and Jan Czerski (1845-1892), who made important discoveries in Eastern Siberia; Benedykt Dybowski (1833-1930), who explored the fauna of Baikal Lake. Paweł Edmund Strzelecki (1797-1873) became famous in Australia and Tasmania, discovering, for example, the highest peak of Australia Alps, which he called the Mount Kosciuszko. Another pole of that time, Jan Stanisław Kubary (1846-1896), was working mainly on the ethnography and wildlife of Micronesia. The conqueror, called by inhabitants "a ruler" of Madagascar Island, was Polish and Hungarian nobleman Maurycy August Beniowski (1741-1786).

${ }^{11}$ Compare, for example, real opus vitae of Andrzej Kajetan Wróblewski (2007), entitled Historia fizyki. Od czasów najdawniejszych do wspótczesności. The Wróblewski's book got the award for the best scientific book "Academia 2007", as it was derived from the author's lectures given around 30 years at the Warsaw University. The book discusses the great history of the beginning and development of physics, ranging from ancient civilizations to the achievements of modern physics. The author not only presents the beginning and development of scientific ideas of physics itself, but also includes scientific achievements in areas closest to physics, which are astronomy and chemistry. There is also huge processional literature of this subject.

${ }^{12}$ An obscure interesting detail is that at the beginning of the 19th century, first chairs of history of medicine came into being. At first in Europe, Polish scientists were giving lectures there, e.g., Franciszek Kostecki (1758-1844) in 1809 at the Cracovian University. At the same year, another Polish scientist, Hiacynt (Jacek) August Dziarkowski (1747-1828), was giving lectures on physiology at Warsavian Akademia Lekarska. Konstanty Porcyanko (1793-1841) was also Polish and he started giving lectures in 1826 at the Wileński University. It started regular academical lectures from that discipline. That was the beginning of the first scientific works, thesis, medical newspapers, professional laboratories, etc.. More about it can be seen in the collective work entitled Historia medycyny (Brzeziński, 1988, pp. 15-16). There is also huge professional literature on this topic.

${ }^{13}$ The leader of such kind of works of European size and world extent was the Polish priest Stefan Pawlicki, who with another Polish resurrectionist, father Piotr Semenenko, not only created a basic thesis to Rerum novarum encyclical of Leon XIII from 1891, but also had probably created other papal documents, thanks to which, they became also co-originators, popularizers, and promoters of this, what we call today Catholic social science, social philosophy, and biblical archeology (see mainly works of Pawlicki, 1884). More about it, see the work of Mylik (2005). There is also a huge professional literature on this topic.
} 
scientific institution, research institute, technical school, scientific periodical, professional library, civilization museum $^{14}$, cinematographic hall, theatre ${ }^{15}$, house of fashion, cultural centre, sport stadium, art atelier, project work-room, set of chambers, financial institution, insurance company, etc.. From that comes not only a historical need of closing or transferring traditional small workshops into new industrial establishments, but also leaving the old-fashioned scientific branches and transferring them or moving to modern disciplines of "positive sciences". 16

No wonder then that we are dealing not only with new economic needs, social changes, or technological achievements, but also with until now completely unknown needs or new disciplines of science, art, or culture.

All historical necessities of civilization transformation, resulting especially from historical consequences of the creation and course of great scientific and technological revolution and connecting with the creation and development of many new positive sciences, made the now unknown social needs, concerning not only new classes, structures, or social orders, but also opening new polytechnic faculties, vocational schools, professional laboratories, research centers, university libraries, scientific foundations, specialist publishing houses, technical periodicals, etc.. ${ }^{17}$

In other words, all revolutionary historical events, epoch social changes, structural economic achievements, great scientific discoveries, modern technological inventions, geographical escapades, etc., which took place in contractual years of 1789-1918, caused indirectly a renaissance of encyclopaedism and directly a birth of positivism, lasting until decadent neopositivism of our times. ${ }^{18}$

\footnotetext{
14 The precursors of modern museums are believed to be first public collections of paintings (Pinakoteka) established in Acropolis. The first museum is also thought to be established by Ptolomeus I of Soter at the beginning of the 3rd century BC, scientific centre in Alexandria, which is known today as the Alexandrian Museum, because it was connected not only with famous Alexandriam Library, but also through centuries collections of Renaissance, Enlightenment, and modern times refered to it. Still, only in the second half of the 18th century, really world's first museums were set, for example, Florentine Galleria degli Uffizi, Galleria Pitti, Muzeo Nazionale in Naples, London British Museum established in 1753, and Paris Louvre Museum established in 1793. A breakthrough in establishing world's museums occurred in the 19th century, when first national art galeleries were created, for example, National Gallery (1824) in London, Kunsthistorisches Museum (1891) in Vienna, Prado (1819) in Madrid, Galeria Drezdeńska (1560) in Drezno, Ermitaż (1764) in Leningrad, or Muzeum Narodowe (1862) in Warsaw. Finally in the 20th century started a wide change of old and new museums into modern scientific centries, where we still maintain, examine, etc. different kinds of museum collections.

${ }^{15}$ Compare the newest and first Oxford edition of the work, entitled The Oxford Illustrated History of Theatre, by Brown (2001) who collected studies of Oxford specialist writing about 4,500 years of history of existing theatre phenomenon.

${ }^{16}$ For example, a Polish expert of this period, Janusz Pajewski (1907-2003), described that civilizational-historical phenomenon of those words: "The development of scientific research, creation of new disciplines and specializations caused rise of number of scientific publications - books, newspapers, bulletins which become a connection among scientist of different countries. Need of closer cooperation and charge of thoughts at least made scientists to create an institution, which would connect academics of different countries. As a result of discussion realized from English scientists side on the convention of representatives of science societies in Wiesbaden in October 1899 an International Association of Academies was created in 31st July 1900, active until the 1st World War" (Pajewski, 1967, p. 290). To confirm his ideas, Pajewski (1967) used examples of historical development, such as physics, chemistry, mathematics, medicine, psychology, history, and philosophy.

17 In 1836, the famous French political writer, Alexis de Tocqueville (1805-1859) doubted whether publishing a newspaper could bring major profits to its publishers. So, he advised the businessmen not to invest in press business. Still in less than a quarter of century later, press business became an extremely profitable activity, not saying about modern profits of a whole press business, whose owners became financial press barons. They not only had gigantic fortunes of international media concerns, but also became the fourth estate in the modern world.

${ }^{18}$ New positivism should not be here understood only as a philosophical concept declared by the representatives of the so-called "Viennese Circle", operating in the 20th century, but as a modern philosophical reality, which, for example, Tatarkiewicz (1981, p. 5) dated from "around 1830, this philosophy has its beginning, which we may concern for modern. What was before this date, belongs to the past, what came after it, belongs to the present times or at least leaded directly to it. Comte's, J. St. Mill's or Marks's ideas, which came into being right after 1830, lasted to our times. It's from those ideas or from fight with them grew ideas of XX century".
} 
The historical necessity became everything that happened then in politics, economy, science, technique, customs, sport, or religion, to use in a practical way, to describe theoretically, carry scientific research, teach methodically, gather systematically, give access safely, popularize spectacularly, etc.. To that all form of encyclopaedia or dictionary of the Enlightenment times was not enough. ${ }^{19}$ The necessity was an institutionalized sphere of politics, industry, trade, technology, art, culture, sport, tourism, religion, etc., ${ }^{20}$ which lasts without stopping until now, as the so-called "the great era of industry revolution". It lasts despite the new changes and development perspectives (information, multimedia, cosmic), modern challenges and needs of everyday life (individual, social, mass), and finally, all those eternal civilization threats of humanity like, for example, unpredictable behavior of men (murders, suicides, doping, drug addiction, alcoholism, etc.), moral dilemma of humanity (abortion, euthanasia, cloning, trade of human organs, in vitro, using condoms, etc.), uncontrolled conflicts, dangers and military alliances (local, national, and global ones), unprecedented facts of world's vandalism, violence, and terror (kidnapping, terrorists attacks, ritual violence of the religious sects, destruction of monumental buildings, priceless works of art, items of sacred cult, and other world's cultural heritages of humanity), or finally not regulated naturally world's climate changes (global warming, fight with elements, protection of endangered species of fauna and flora, etc.). ${ }^{21}$

Finally, no wonder then that in the discussed period of time, completely new encyclopaedia's era appeared, but not of the enlightenment kind of Voltaire and other encyclopaedians, but in modern positivists edition. They survived until today in little changed form of thinking as neopositivists or as postmodernists, having a general idea little changed.

\footnotetext{
19 Joseph Charles Panckoucke (1736-1798), a French editor of last volumes of Encyclopaedia in 1780, seemed to understand that further continuing this famous work of encyclopaedians does not have much sense in the light of fast development of science of that time or progress of technique and that is the reason why in 1782 he started to edit Encyklopedie méthodique though not as an alphabetical dictionary of historical people or factual index of scientific concepts, but as a series of huge scientific monographs, including all branches of human knowledge of that time. Still editing of this encyclopaedia not only prolonged, but was also never finished. Its obsolescing result of synthesis of progress of sciences and technique development was much quicker than editing the next volumes of Encyclopaedia.

${ }^{20}$ One of the Polish history writers of that time, Janusz Pajewski, confirmed it. He claimed that: "Second half of 19th century was not only the period of huge economy development, but also a great boom of culture. Creating a world market and technique progress much widened a traditional circle of fast developing west European culture: it was enriched by fast developing intellectual life of America and Asia and peripheral until now European countries: Scandinavia and mainly Russia. Influence of culture progressed not only across, but also to the depth by the developing education in particular countries on every level, a chain of libraries was expanded, editions of books and periodicals. To the growing social needs answered quality and quantity of progress of technique and culture popularization. Editing the industry development, print technique progress, development of theatre technique and the beginning of film had its role in it" (Pajewski, 1967, pp. 289-290).

21 "Today human cultural and natural heritage is more and more threatened by being destroyed not only because of damages caused by traditional reasons, but also because of social and economical changes, which aggravate the situation by phenomenons of even more dangerous damages. Damaging or annihilation any common wealth that belongs to cultural and natural heritage constitutes irreversible depletion of heritage of all the nations (...). In the face of size of new dangers, that threaten to these goods, whole international society should take part in defending the cultural and natural heritage of huge universal value by helping collectively, not replacing the help of the government, but to supplement it" (Accepted on November 16, 1972 at the General Conference of United Nations for Upbringing, Science, and Culture, Paris, October 17-November 21, 1972 on its 17th session). The full text was published in Polish in statute book from 1972, nb 32, pos. 190 (see series of great subjects entitled Katastrofy i zagrożenia we wspótczesnym świecie, Baturo, 2008, p. 288). This work shows not only main threats for modern humanity, but also ways of preventing and solving such problems as hunger and malnutrition, organized crime, poverty, illnesses, addictions (drugs, alcoholism), disasters, or ecological catastrophes. From the same series of great subjects, see book Konflikty wspótczesnego świata (Seria Wielkich Tematów, 2008, p. 304), where political, ethnic, and military conflicts of human civilization of the 20th and 21 st centuries are shown. See also work entitled Idee i ideologie we wspótczesnym świecie (Seria Wielkich Tematów, 2004, p. 304), which shows the most important modern political and social ideas, such as fundamentalism, globalization, European integrity, neoliberalism. From among Polish authors, see works of Brunon Hołyst, who in such interesting publications, as for example, Samobójstwo. Przypadek czy konieczność (Hołyst, 1983), Przywróceni życiu (Hołyst, 1991), Wiktymologia (Hołyst, 1998), Kryminologia (Hołyst, 2001), Kryminalistyka (Hołyst, 2000), Suicydologia (Hołyst, 2002), showed the phenomena and explained the causes of basic dangers for men in a modern world.
} 
All those changes, needs, or challenges given above of positivism made the philosophers of that period to look close to all this, which happened around them in different spheres of political, economical, social, scientific, technological, military, artistic, moral, or religious life. Thinkers of that incredibly interesting time could not only watch light-heartedly, behave impassively, or be completely neutral to all this, which often had any direct or indirect influence on them: on their personal life or their relatives' lives. That is the reason why not only from the scientific point of view, those philosophers were observing the scientific events, economic and social changes, or military activities.

That is the reason why they studied with all the ways they knew and all the means they had, like we often do and what will probably be done in future an origin of many myths, beliefs, and historical legends. ${ }^{22}$ They $^{2}$ also evaluated the authenticity of historical events, credibility of rescued discoveries and archive excavations, the truthfulness of less or more significant historical figures, etc.. ${ }^{23}$ They discussed with others about the current events, which happened in the country, they tried to influence ideally foreign affairs, they became ambassadors of good hope of pressed nations, they engaged themselves in diplomatic games, military alliances, and political parties of different nations, they took part in peace mediations between conflicted social, local, national, or world sides, etc.. ${ }^{24}$ They created far-reaching colonial plans of their countries, condemned the shortsightedness of colonial politics of other nations, and tried to preserve the language, customs, and traditions of the colonized people. ${ }^{25}$ They evaluated the objective meaning of new scientific truths and realistic usefulness of modern technological inventions and initiated them, and they got accustomed with the new scientific truths, technical inventions, geographical expeditions, artistic vents, cultural turns, etc.. $^{26}$ They admired genius of great scientists, the inventiveness of inventors, courage of the travelers,

\footnotetext{
${ }^{22}$ See works of such authors, as for example, Barbour (1976), Bultmann (1958), Malinowski (1990), Levi-Strauss (1958), Eliade (1949), and many other works of both Polish and foreign authors.

${ }^{23}$ The main figure of this kind of historical and philological research of the times of positivism was French philologist, historian and skeptic in one, Ernest Renan (1823-1892), whose works in 8-volumed Historia poczqtków chrześcijaństwa, published in the period of 1863-1883 and his 5-volumed Historia narodu żydowskiego published in the period of 1888-1894 were and are, despite risky thesis, the best works of synthetic French humanities, claimed Tatarkiewicz (1981, p. 126). See also classical, filological, historical, philosophical, and even theological criticism of Renan's works done by Pawlicki (1905), entitled Żywot i dzieła Ernesta Renana.

${ }^{24}$ See the work of Lilla (2006), entitled Lekkomyślny umyst. Intelektualiści w polityce, where he described intellectual strives with political tyrannies of the 20th century of such scientists as M. Heidegger, H. Arendt, K. Jaspers, C. Schmidt, W. Benjamin, A. Kojỳve, M. Foucault, or J. Derrida, stating to be for or against them. A similar topic was worked on by a Polish author, Maria Hirszowicz (1925-2007), who even got an award of Polityka Magazine in 2001 for her last work entitled Pułapki zaangażowania, Intelektualiści w stużbie komunizmu (Hirszowicz, 2001). See finally the work of Polish Nobelist, Czesław Miłosz (1911-2004) who, in Zniewolony umyst, further tried to show how human thought in peoples' democracies (Miłosz, 1989).

${ }^{25}$ A term postcolonialism was even created in professional theme literature, which refers to a whole branch of philosophical and even literary theories. They concern many issues on the heritage of European colony powers and process of decolonization in the 20th century. Postcolonialism in literary meaning is a critical analysis of literature created in the countries, which were or still are colonies of other countries, also a literature written by citizens of countries that were settling the colonies. That is the reason why a post-colonial literature deals generally with the problem of developing a national identity in such societies, differences and mutual cultural impact between the society of colonizers and the conquered nations. It also deals with mutual relations between former colonies and their former colonial powers. Postcolonialism as a programme of scientific research over post-colonial literature developed in the 70s of the 20th century, and its creator was Edward Said (1935-2003) with his important work Orientalism (Said, 1978). Other important positions of professional literature of this subject are also works of such authors as Parry and Sprinker (1998), Fanon (1961), Césaire (1950), Spivak (1990; 1999), and many others. Eve M. Thompson wrote about Poland and other post-Soviet countries used the term "post-colonialism". The same term was used by Janion (2007) in her book Niesamowita Slowiańszczyzna: Fantazmaty literatury.

${ }^{26}$ See the works of such authors as Baker (1931), Kramer (1953), Blond (1960), Szafar (1974), and many other both Polish and foreign works.
} 
wisdom of prominent statesmen, arts of writers, artists, actors, etc.. ${ }^{27}$ They also envied the fame to the creators of new scientific disciplines, new art areas propagators, activists of avant-garde cultural branches, etc.. ${ }^{28}$ They travelled by new means of transport, they were interested in stock, invested a lot in banking, trade, industry, insurance, etc.. ${ }^{29}$

\section{Historiosophical Origin of the Renaissance of the Global Phenomenon of Sport and Tourism}

One of the typical examples of all those great civilization changes of humanity was not only the modernization of the ancient ideas of the Olympic Games, but also the practical implementation of its classical pattern of idea to our modern sport life by establishing first Olympic societies and organizing every four years modern summer and winter Olympics, recreating ancient Olympic sport disciplines and finding new ones, building first Olympic stadiums and constructing many kinds of new sport equipment, establishing first national sport clubs and creating international sport organizations, and finally, making lists of sportsmen, disciplines, games calendars, record catalogs, kinds of medals, coach categories, referee classes, activists functions, fan rallies, and many other modern creations of practices and theorists of such widely understood sport today. ${ }^{30}$

\footnotetext{
${ }^{27}$ Not only philosophers admired that, but also readable writers found it fascinating, such as Rudyard Kipling (1865-1936), Joseph Conrad, or rather Józef Teodor Konrad Korzeniowski (1857-1924), Herbert George Wells (1866-1946), Robert Louis Stevenson (1850-1894), Jack London, or rather John Griffith Chaney (1876-1916), and others gained an unforgettable place thanks to their popular species of literature fictions even today.

${ }^{28}$ Compare what famous philosophers delivered to people with how they treated their relatives. For example, Rousseau, Marks, or Sartre and also such famous writers as Schelley, Ibsen, Tołstoj, Hemingway, and Brecht in the well-known book of Johnson (1988). In a similar style, the Nobelist (economics), Friedrich August von Hayek (1899-1992), wrote his book The Intellectuals and Socialism (Hayek, 1949). Today, to this kind of works, Furedi (2006) referred in his book Where Have All the Intellectuals Gone? Confronting 21st Century Philistinism.

${ }^{29}$ It is said of Emmanuel Kant that from Greek or medieval times, nobody in practice lived such philosophically as this legendary philosopher from Królewiec. But he even made from his modest pension a small fortune of 21,000 talars. It did not happen because he saved his money, but because he invested for years his small savings in different businesses of his friends and businessmen, whom he preferred to spend time with rather than with people of science. More about it can be seen in academic script from 1886 of Pawlicki (2000) entitled Historia filozofii nowożytnej.

${ }^{30}$ First proved Olympic Games took place in 776 BC. They were played usually every four years in Olympia in ancient Greece. In $393 \mathrm{BC}$, it was played there for the last time. Then, people have almost forgotten that event for centuries; they were remembered again in Renaissance. First records of ancient Olympics were found in the documents of such Renaissance writers as Matteo Palmieri (1406-1475), Hans Sachs (1494-1576), and Thomas Kyd (1558-1594). The first come-back of the Olympic idea was in the 19th century, when in 1833 in Sweden, the first Olympic Society was established. It is that organization that gave the idea of organizing one year later Scandinavian Games to memorize the ancient Olympic Games. They took place for the first time on July 14, 1834 in Ramlösa in Sweden and two years later they managed to organize the second and the last games of that type. Fortunately, this Scandinavian idea of raising the ancient Greek Olympics took over a rich Greek philanthropist and veteran of Greek-Turkish wars, Evangelos Zappas (1800-1865). Thanks to his generosity since 1859 in Greece, Olympic gymnastic games took place every four years. Finally, they managed to play only three modern Greek games in 1859, 1870, and 1875. They were national like the Scandinavian ones, because only Greeks took part in it. At the same time, archaeological works were conducted in Olympia and it made the world more interested in ancient culture and as a result, it increased a modern idea of raising the Olympic Games. The first person, who demanded organizing the international Olympic Games, was a Frenchman, Pascal Grousset (1844-1909) in 1888. A modern idea of Olympics found many imitators and fans. A main propagator was a French baron, Pierre de Coubertin (1863-1937). It was his initiative to call in June 1894 in Paris an international congress for raising the Olympic Games with 79 delegates and 2,000 guests from different parts of the world. As a result of this convention, a motion was carried out on June 23, 1894 of formal establishment of the Olympic Games of the modern era. To realize this aim, the International Olympic Committee was set. It consisted at first of 15 representatives of 15 countries, which took part in that historically first session of the French congress. The first president of the committee was Greek, Demetrius Vikelas (1835-1908), who convinced the chairmen to run the first Olympic Games in Greece rather than in Paris, France, as it was mentioned at the beginning. That is the reason why the first summer Olympic Games took place in Athens in 1896 and the first winter Olympic Games in Chamonix in 1924. Then, however, from 1896 to 1925, the president of the International Olympic Committee was baron de Coubertin and it is then that the world's era of modern Olympic activity started.
} 
The same situation is with the renaissance of tourism, which, like the phenomenon of sport, has its roots in ancient and medieval times, when it was treated like a kind of pilgrimage. ${ }^{31}$ A modern understanding of tourism and its historical beginning and civilizational blossom especially in the latest times owe to a modern era, when it happened because of all those civilization changes: tourism could develop thanks to the trade tracks, railway, travel routes, expeditions, technological inventions, industrial products, and many other civilization achievements of humanity of that time. That is the reason why we have not only first touristic tracks in almost all world directions or first tourist expeditions to all continents, but also first professional travel agencies and mountain first-aid stations and staying in spa resorts, first ski slopes and cable railways, sea resorts, and even modern renewal of medieval idea of tradition of pilgrimages. ${ }^{32}$ On that basis, we could generally say that in the mentioned period of civilization changes of humanity, rebirth and incredible development also happened in the world of "modern era of world tourism and modern epoch of Olympic sport". It helped to create such spectacular phenomenon of sport, tourism, or recreation on almost all civilized world.

Since then, scientific research on a wider scale has begun to figure out some of the answers. For example, why do people want to travel or practice a particular discipline? In what way should we practice sport or tourism?

To describe, in particular, all that happened then and what was its final impact on the present state and future development of sport and tourism in the whole civilized world, those remarks are only a kind of a proem to such thorough studies or only a scientific contribution in that extent.

\section{Historiosophical Essence of the 19th Century World Civilization Transformations}

There is an almost infinite number of examples of this kind that can be found in the history of human civilization, especially within the last two centuries, and all of which, taken together or separately, are still undeniably an important historical testimony of cultural changes. Furthermore, these examples show that the reaction of many contemporary philosophers, writers, scientists, and even ordinary people from the positivism

\footnotetext{
${ }^{31}$ It is commonly believed that the oldest religious pilgrimages are also the first kind of trips for tourism, which was done in biblical times by the selection of Jahwe, done also in the times of Mahomet (570-632), when believers of Allah started to go on pilgrimages to Mekka and Medina, continued to our times by the religious Buddhists, who go to many Buddhist temples, ascetic Hindus, who wash themselves in holy waters of the Ganges River or Christian missionaries, who preach a Gospel to people on the whole world. Trips for tourism also take place in the ancient Egypt, where people were traveling to take part in the religious and public holidays. At that occasion, those "tourists" could not only see nature by the Nile River, but also sightsee the whole Egyptian civilization, especially the pyramids. Religious destinations were dominant in the trips taken by the ancient Greeks, who usually traveled to well-known even today oracles in Delphos or to the temple of Zeus in Olympia. In ancient Hellada, contrary to the ancient Rome, roads were not built, so most of those "trips for tourism" of Greeks of that time were by sea. In the empire instead, a huge net of roads and inns was created and the safety of the travelers was set by the law regulations. Romans were also travelling for health and relaxation to such resorts of the empire as Baden, Baile, Herculane, Vichy, Baiae, Neapol, Capri, Bath, Puteoli, and others. In middle ages, there was a sudden stagnation in tourism. Mai travels had a pilgrimage character. Christians of that time usually travelled to Rome, to the Holy Land, or to the grave of St. Jacob the apostle to Santiago de Compostela. Ancient Arabs, instead, were taking such trips to trade. We may also say about "science tourism" in case of young European students of different nationalities who, like Poles, Czechs, or Germans, were going to study in foreign medieval universities in Italy or France. We cannot also forget an influence on medieval tourism of expeditions of travelers like Marco Polo (1254-1324), who went up to China, Francesco Petrarka (1304-1374), known for his travels across Provencal Alps, or Muhammad ibn Battuta (1304-1377), travelling around Asia, Africa, and Europe. Since the 14th and 15 th centuries, the era of great geographical discoveries starts, creating the main understanding of the world's touristic movement.

32 Compare the works of Dziubiński (2006; 2007).
} 
era was firstly a renaissance of encyclopedism and then a newly created positivism. ${ }^{33}$ This philosophical system grew out of the need of its time and lasted for years, eventually transforming into the contemporary post-positivism mentality of today's and, who knows, maybe the future man. It is not from today that we observe historical and social changes or economic transformation, concerning the whole civilized humanity.

On this (even briefly presented) basis, it is important for us to draw a conclusion that positivism in the historiosophical notion has always had indisputable historical merit and equally invaluable cultural achievements in creating a whole history of human civilization. That is the reason why it still has civilizational potential, which can be unknown to us. On one side, that stimulates human's curiosity in the pursuit of an answer to the typically positivist question: "How was the world created?". On the other side, as a result of principle assumptions (intentional or unintentional), there exists an impossibility to answer (directly or indirectly) a much more important, ontic question: "Why was the universe created?".

However, on the other hand, when we are seeking the answer to the generally formulated question: "What is the world like?", we also cannot find the answer to the question: "Why was the whole universe created?". Then perforce, scientific positivism and Christian thought would join together in an attempt to find a common answer to the final riddle of the creation and end of the world.

This positivist vision of endless, unanswered questions was outlined at the beginning of the 19th century, by Sophie Germain (1776-1831). Today, she is an almost forgotten though brilliant French mathematician. She was perhaps the first who wrote that: "Rather than studying the causes of phenomena, as it was done previously to this time, they began to consider the phenomena themselves. The question changed from why to how. In this way, the diligent scientists started thinking about the nature of things. They made a positive observation and renounced the satisfaction of explaining them, confident, that the liaisons between their observations would be found at a later date. This was the beginning of the epoch of the true knowledge of nature. Until now we had been imagining it but then we saw it for the first time". ${ }^{34}$

The above quotation and, at the same time, the first motto of our work comes from Oeuvres philosophiques de Sophie Germain, ${ }^{35}$ which is simple in words and essential in its content and is an ideological interpretation of the 19th century French positivist philosophical program, because it is a short summary of the

\footnotetext{
${ }^{33}$ In Poland, according to Henryk Markiewicz in Polish humanities, positivism is a period of fundamental encyclopedic and dictionary works. Here are some of the most important, in chronological order: Polish bibliography of Karol Estreicher (from 1870), which registered alphabetically and chronologically Polish works from the 15th to the 20th century. The Geographical Dictionary of the Kingdom of Poland and Other Slavic Countries (1880-1914, Vol. 16), edited by Filip Sulimierski and Bronisław Chlebowski; the Book of Proverbs Parables and Wise Sayings (1889-1894) by Samuel Adalberg; Wielka encyklopedia powszechna ilustrowana (Great Illustrated Encyclopedia) (1890-1914, Vol. 55, till letter P); Poradnik dla samouków (Guide for Self-taught People), which contains methodological tips from various fields of science (1898-1911, Vol. 6), edited by Stanisław Michalski; Encyklopedia staropolska ilustrowana (Old Polish Illustrated Encyclopedia) (1900-1903) by Zygmunt Gloger; Polish dictionary (1900-1927, Vol. 8) edited by Jan Karłowicz, Adam Antoni Kryński, and Władysław Niedźwiecki; Dictionary of Polish Dialects (1901-1911, Vol. 6) Jan Karłowicz; Markiewicz (1978, p. 412).

34 "Jusque-là, on avait toujours cherché les causes des phénomènes. On commença alors à les considérer en eux-mêmes. Au lieu $\mathrm{du}$ pourquoi, on voulut savoir le comment de chaque chose. Une foule d'observateurs laborieux examinèrent la nature des faites. Ils renoncérent couragesement pour eux-mêmes à la satisfaction de les expliquer, dans l'espérance de léguer à leurs successeurs une masse de connaissances positives, dont la liaison se dévoilerait nécessairement dans un temps plus éloigné. Alors, et seulement alors, on commença à connaître la nature. Auparavant, l'homme l'avait imaginée; il la vit pour la première fois" (Germain, 1896, p. 124).

35 The basic sources about Germain's life and work are the letters (from and to her) and the article by Guillaume Libri published in Journal de Debats on May 18, 1832. Her biographer, Hippolyte Stupuy, based his book on these and few other sources. It was first published in La philosophie positive (no. from Sepember and November 1896) and later reprinted as an introduction to Oeuvres philosophiques de Sophie Germain, Paris 1879. This work was reissued in 1896. This second edition is an object of our study and is quoted in short Oeuvres.
} 
whole (the multi-volume and often enough) complex theory. The author of these words became the precursor of the French positivism and gained a place in the history of the general philosophy. Not only did the founder of French positivism, Auguste Comte (1798-1857), but also the followers of his philosophy, generally amicably agree that Sophie Germain was their spiritual antecedent. Think so, because not only her thoughts are similar to the most important assumptions of positivism, but even Comte himself admitted that thought similarity in his work entitled Course on the Positive Philosophy. ${ }^{36}$

It is no wonder that her scientific proposal quite quickly became an anticipation of the later philosophical positivism, whose representatives, including Comte, stated that we were not at the creation and will not be at the end. That is the reason why it is impossible for us to find out about the beginning or the end, as believed, e.g., Émile Littré (1801-1881) or Célestin le Barbier de Blinières (1823-1905). ${ }^{37}$

This French thinker had accurately outlined what later Comet and his students precisely and laboriously worked out in multi-volume books. Also, the whole reformatory program of contemporary science is derived from her. Generally speaking, the reform was to cease asking about why the world exists and to start answering what the world is like. ${ }^{38}$

According to Germain, the fundamental cause of human mistakes, dating back almost to the beginning of the history of the human race, is an external, metaphysical confidence that there is a sense in looking for the beginning of all things. ${ }^{39}$ Only mathematicians did not do such searches, in her opinion, and therefore remained free from these kinds of metaphysical errors, because it has always presented the human mind with a real and a completely innate type of truth. ${ }^{40}$ She thought that the reform of an exact science could be done only by means of mathematics. The exact science emerged from the general philosophy and soon came to the same certainty that mathematics had already had. The reform of the French scientist was supposed to work on the assumption that we should stop searching for the reason of the phenomena and just examine what the phenomena of the world are.

In other words, according to Germain, one should stop asking why or where from and start searching for what or what the phenomenon in its essence is.

\footnotetext{
${ }^{36}$ If S. Germain brought only her contribution to the field of mathematics, she would never be mentioned in the universal history of philosophy or in the French positivism. However, in her works, she put a lot of her philosophical thoughts. Comte and other positivists renovated not only her earthly tomb but also revived her spiritual legacy. It happened mainly thanks to her little work entitled: Considérations générales sur l'état des sciences et des lettres aux différentes époques de leur culture, which was published posthumously by her nephew Armand-Jacques Lherbette in 1833. This little book would probably be completely forgotten, as that happened with many other works printed every year in Paris, if Comte did not promote and referred to it. In his Course on the Positive Philosophy, he spoke very highly: "It would be a superficial understanding of Madam Sophie Germain if we judged her only from the geometric point of view. However her contribution to mathematics is significant. Her excellent work, which was published after her death in 1833, about 'State of science and literature in different periods of their culture' shows lofty philosophy, the wisdom and energy, about which few today's prominent minds have comprehension. I will always attach a great importance to the general agreement, which I notice between these writings and my own standpoint on the whole mental development of mankind" (Comte, 1864).

${ }^{37}$ Cf. Littré (1864, p. 107), August Comte et la philosophie positive. Célestin le Barbier de Blinières (1823-1905) thought likewise. He expressed teaching of his master: The human spirit can always reach only to the "how", but this "how" is enough for the reality of our lives. Cf. Exposition abrégée et populaire de la philosophie et de la religion positives (de Blinières, 1857, p. 83).

38 For more on this topic, see Mylik (1997). There is also a basic bibliography about her life and work.

${ }^{39}$ Cf. Chapitre, I., "Comment les sciences et les lettres sont dominées par un sentiment qui leur est commun" as quoted in Germain (1896, p. 77) and next.

${ }^{40}$ C'est de cette époque, à jamais mémorable, qu'il faut dater l'aliance entre les sciences mathématiques et les sciences physiques. (Ibid, p. 121).
} 
This reform, or rather its draft, soon became an ideological program for the whole positivist science research, including positivist philosophical deliberations and later religious actions of the first French founders of positivism.

Such a notion of reform of contemporary philosophy is also based on the thoughts of d'Alembert (1717-1783), Turgot (1727-1781), and Condorcet (1743-1794). Comte and his followers tried to realize not only a program of positivist philosophy (modern at that time) but also a credo of a new inherent religion! $!^{41}$

However, according to Polish neo-scholastic philosophers of that time, e.g., Stefan Pawlicki who lectured at the Universities in Warsaw, Rome, and Cracow, the positivist philosophy led to agnosticism, skepticism, and finally to atheism. By imposing on the human mind a prohibition to examine the beginning and end of all things, thereby closing the only way of knowing God (in the philosophical sense), this breeds agnosticism, skepticism, and atheism in the human mind. One cannot philosophically know God, without recognizing the traces of his presence in all creatures. Almost all Christian thinkers were unanimously agreed on that point. By not letting our mind follow the classic path of causality, that is cognition from the effect to the reason, we enable its passage from a finite world to the infinite being: to God in the theological order. This, in turn, eventually leads, sooner or later, to the strongly developed atheism.

This way of thinking can put one in a difficult situation. Germain found herself in such a position, namely, how to explain the ontic right that all phenomena are born and die? How can we explain that beings exist, since they might as well not exist, because they have no reason for existence in themselves, but they find it beyond themselves, outside themselves?

Neo-Thomistic metaphysics finds the ultimate right of every being in the Absolute-God, while Germain thought that the world in general is something unique and necessary. ${ }^{42}$ In fact, however, it is the materialistic thesis, because almost all materialists who do not accept God in their system of thoughts, often at the same time, show that the phenomena of the world are accidental and its existence is necessary. ${ }^{43}$

Thus, Germain rejects the existing ontic differences and classic relationships between God and the world, an essential and accidental being, matter and sensuality, body and soul, etc.. She puts in this place á la monistic, mathematical point system, the balance of which will be the truth for the mind, the beauty for the imagination, and the good of the heart. Apparently, it seemed to her that only one right rules all the phenomena of the world

\footnotetext{
${ }^{41}$ More information about philosophy and religion, see S. Pawlicki, Studiach nad pozytywizmem, "Przegląd Polski”, Cracow 1884/1885, Vol. 75, pp. 215-239, pp. 522-566; Vol. 76: 1884/1885, pp. 503-523; Vol. 77: 1885/1886, pp. 70-110; Vol. 78: 1885/1886, pp. 217-248, pp. 526-548; Vol. 79: 1885/1886, pp. 355-387; Vol. 81: 1886/1887, pp. 462-495 and copy 1885. According to contemporary historian of philosophy Frederick Copleston also, "Mill is thus in agreement with August Comte that the so-called religion of humanity is the religion of the future, though he has no sympathy with Comte's fantastic proposals for the organization of this religion. At the same time he does not rule out belief in a finite God with whom man can co-operate. And though his idea of religion is clearly not such as to satisfy Kierkegaard or indeed anyone who understands religion as involving absolute self-commitment to the personal Absolute, he does not think, like some empiricists before him, that religion can be disposed of either by a psychological account of the way in which religious belief could have arisen or by drawing attention to the evils which have been done in the name of religion" (Copleston, 1989, p. 96). There you can find a professional literature of the subject.

${ }_{42}$ See Ajoutons que, suivant notre conviction intime, ce fait unique doit être nécessaire in Germain (1896, p. 131) and next. For Germain, everything what happened had to be happened of necessity. According to her, if we distinguish accidental things from necessary things, we do not know all conditions, thanks to which these accidental things happened (Ibid, p. 131).

43 "En observant la manière dont il procède, nous verrons qu'il agit toujours suivant une méthode constante; et, après avoir suivi les différentes époques de la composition, il deviendra évident que la littérature la plus élevée, comme les découvertes dont s'enrichit la science, ont été inspirées par un sentiment d'ordre et de proportions qui est le régulateur de tout mouvement intellectuel. Ne nous en étonnons pas: l'esprit humain obéit à des lois; elles sont celles de sa propre existance; elles lui fournissent une mesure commune entre toutes les existences qu'il conçoit en dehors de la sienne; elle deviennent nécessairement le mobile de tous ses travaux, la source de tous ses plaisirs" (Ibid, p. 81).
} 
in every area of social life, in all scientific disciplines, and even in each domain of art. ${ }^{44}$ This law was for her so universal and inexorable that nothing is above it or under it, and there was no place for a free and rational will, either human or divine. That is the reason why she conjectured scholarly visions, like the ancient Pythagoreans, that the mathematical formulas will be commonly used even in ethics, politics, or metaphysics, and what is even more interesting, in reference to good taste or the aesthetic sense. ${ }^{45}$

All of this briefly explains both materialists' sympathies to the abovementioned way of thinking and a similarity of views between Germain and the positivists. As Carl Theodor Göring (1841-1879) said, her work is not only a thorough and witty introduction to contemporary philosophy, ${ }^{46}$ but something more. It is a work that sums up in a clear, mathematical, and graceful feminine way the materialistic and positivist philosophy of the 18th century. Germain's philosophical views are the bridge between Condorcet and Diderot's school and Comte's mathematical skepticism. They help in giving a proper account of positivism which, in her works, appears clearly as a continuation of modern atheism, which has been dragging on since ancient times, but especially since the encyclopedism epoch was exposed.

Therefore, it is believed that the arising positivism in that time should not be treated today as just Germain's scientific research program. It should also be recognized in terms of the newly (at that time) established positivist methods (besides, they have been used until today in natural science), as a philosophical system that developed initially in France under the influence of Comte and in England under Mill. Finally, the positivism should not be extremely presented in terms of religion, as it was first done by French positivists, or as it is being done by American scientologists today.

Positivism, then being born under the influence of these all abovementioned transformations of civilization, for the last two centuries has become not only an essential thought pattern for most civilized people of the Western world, but now has also been the predominant mode of action for the practical contemporary man. The Man who has almost stopped asking why the world was created and is content with only answering what is the nature of the world!

Germain herself discerned the contemporary change in scientific thinking, especially among people she labeled in French une foule d'observateurs laborieux, ${ }^{47}$ which after all did not refer only to the les philosophes, as if maybe, e.g., Comte and his followers wanted. Her words referred to "the whole mass of industrious scholars", who not only philosophically watched the world which was changing in front of their eyes, but above all, they made all of these scholarly transformations for humankind. For that, Germain should be regarded not only as a precursor of the French positivist philosophy ${ }^{48}$, but above all, as the unknown pioneer for a bunch of

44 'Dans le chapitre suivant nous verrons, en jetant un coup d'oeil sur l'histoire de l'esprit humain, comment, jusque dans ses écarts mêmes et en vertu des lois de son être, tous ses efforts ont été dirigés vers l'ordre, la simplicité et l'unité de conception" (Ibid, p. 90).

45 Ibid, p. 143 and her words: "Tâchons enfin de fixer notre opinion à l'égard de ce modèle du vrai, de ce type de l'être qui a souvent égaré la raison humaine, et qui, dans nos temps modernes, sert à la guider d'une manière si heureuse que ses progrès, d'abord concentrés entre en petit nombre d'hommes livrés à l'étude, se répandent aujourd'hui dans toutes les classes de la société, éclairent à la fois les sciences morales et politiques, la physique, les arts chimiques et mecaniques, et peuvent fournir aux lettres et aux beaux-arts des lumières nouvelles, des inspirations qu'ils n'ont pas encore rencontrées" (Ibid, p. 136).

46 Cf. "Die Gegenwart", 2 (1885), p. 24 (after Mylik, 1997, p. 152).

${ }^{47}$ Cf. Germain (1896, p. 124).

48 Also in Germany, Dühring paid attention (in his History of Philosophy) to similarities between Germain thoughts and doctrine of positivism. He appreciated Germain "in her compact work about the state of science and literature, you can find much more systematic thinking, than sometimes in voluminous positivist philosophical lectures". Eugen Karl Dühring (1833-1921), Kritische Geschichte der Philosophie von ihren Anfangen bis zur Gegenwart, Berlin 1873, p. 510. Polish historians of philosophy like Stefan Pawlicki or Władysław Tatarkiewicz had similar opinion. They claimed that Germain made a sketch, which was later developed by Comte and his followers. Compare Pawlicki (1885), Studia nad pozytywizmem. Zofia Germain, "Przegląd Polski", 78/1885, p. 141; and his Historia pozytywizmu i szkót pokrewnych, course book, Cracow 1888/1889, p. 8. Cf. also Tatarkiewicz (1981, p. 17). 
scholars of that time, who have remarkably contributed to the creation and consolidation of the positivist attitude in human's consciousness (awareness) in science, which has prevailed until today.

Positivism, in a sense, as a kind of widely understood scientific attitude of a constantly expanding number of people, has recently changed the human way of thinking about reality. As a result of this, both scholars and ordinary men changed their manner of thinking. The ordinary man is no longer satisfied with the knowledge about himself and the world around him. As a result, more and more people do not seem to ask the reason why they and everything that surrounds them exist. ${ }^{49}$

This is what appears to be the essence of the positivist thinking, for both, the first founders of positivist philosophy, as well as for thinkers, politicians, and even ordinary people of today (more in scientific dimension). This issue seems to be the most significant difference between positivist and neo-scholastic thinking. It has become almost a common choice of outlook for contemporary people who, in everyday life, prefer to follow positivist philosophy rather than the neo-scholastic discourse. In their countless, theoretical choices, in the multitude practical achievements, and in many other matters arising originally from all previous civilization transformations, historical needs, epoch challenges, etc..

However, such a stricte positivistic approach to the world that surrounds us is, according to many representatives of maximalism philosophy of the time, only partially positive. Positively, because you have to know as much as possible about yourself and the whole universe. Negatively, because just by positive action or only focused scientific thinking, you cannot find a significant answer to the question of a purely metaphysical nature, namely, why do I and the world that surrounds me exist?

The answer to this metaphysical question is probably the essence of philosophizing for each of us. Almost every man, whether he wants it or not, is condemned to philosophize. This is not without reason, says the world famous Polish scholar Józef Maria Bochenski (1902-1995). Despite the extraordinary difficulties that come with it, it is one of the finest and the noblest things in human life. ${ }^{50}$

Hence, it appears that, in fact, minimalist, including the positivistic philosophical current or scientific way of thinking, was not enough for anybody. Each of us, as many years of historical and philosophical ${ }^{51}$ experience teach, is truly Aristotelian animal metaphysicum, due to its nature strives for intellectual cognition of the whole truth, ${ }^{52}$ its will wants good, and its senses pursue complete pleasure. Therefore, since the dawn of time until the end of it, the questions from astonished people will not cease. Their unceasing philosophical effort to find even a small part of the whole truth about the creation, the ultimate purpose of life, and the

\footnotetext{
49 For more on this topic, see Mylik (2006, pp. 19-24).

${ }^{50}$ Bocheński (1986, p. 20). See also Pieper (1966; 1985, p. 88) and Głombik (2004, p. 173).

51 The historical-philosophical experience of Etienne Gilson is the best evidence for that. He thought that: "Theology, logic, physics, biology, psychology, sociology, economics - all these disciplines are fully competent to solve their own problems by their own methods; On the other hand - and this must be our fourth conclusion - as metaphysics aims at transcending all particular knowledge, no particular science is competent either to solve metaphysical problems, or to judge their metaphysical solutions" (Gilson, 1968, p. 213).

${ }_{52}$ It was understood not only by the US legislature, thanks to which in American courts, the witnesses swear (not only in Hollywood movies) to tell "the truth, the whole truth, and nothing but the truth", but also by ancient Greek thinkers. Their natural desire of the truth was expressed by the philosophical understanding, first of the world, then human happiness, and finally, the existence of the Absolute, even if unspecified at that time. This natural human desire to know the truth, initially expressed mainly by astonishment and curiosity towards the natural world, eventually led to the formation of the first science: classical philosophy. In the methodology of philosophy, such understood and practiced philosophy (metaphysics) was sometimes called the classical conception of philosophy, but not only because it originates in the classical period of Greek philosophy, especially thanks to Plato and Aristotle, but above all because it corresponds to the natural needs, aspirations, and human tendencies to know the truth about reality. Cf. e.g., Bronk and Majdański (1992, pp. 367-390); cf. also Morawiec (1998, pp. 13-65).
} 
absolute end of the whole reality will not finish. It is also the eternal sense (aim) of philosophy (metaphysics), which positivism, in particular, thwarts in us. This is true in both its minimalist way of asking questions and its anti-maximalist response to them.

Therefore, positivism from a philosophical perspective is a rather (minimalist) anti-philosophy than a philosophy in the full sense of the word (i.e., maximalist, classical)!

Furthermore, from a historical and philosophical point of view, there is one more important thing to say, namely, positivism. Although it undoubtedly emerged from the needs of that time, it became the dominant thoughts system not only for its period. It could not completely or properly use or effectively resist all of the civilizational transformations, needs, and challenges, which took place at the discussed time. That is the reason why in the 18th century, philosophy lost the scepter of the queen of science in favor of mathematics. It has not regained the privileged position yet. In modern philosophy, as another world famous Polish thinker of the time Jan Lukasiewicz (1878-1956) rightly points out, somehow the right conception of metaphysics was lost and, maybe with the exception of neo-scholastics, today nobody knows how this queen of science should be understood (Łukasiewicz, 1906).

For this state of affairs, we should blame both, those who followed positivist philosophy and those who did not. Thus, they could not defend philosophy against the decline in prestige. Scientists, who have been sympathizing with the widely understood positivism, effectively pushed aside metaphysical thinking about reality. It has been left out and now it is outside the mainstream of the average man's practical life. As long as the anti-metaphysical, that is in essence a minimalist-positivism scientific trend, will dominate in human thinking and practical activities, a maximalist approach to philosophy (e.g., metaphysics) will be at the far end of science and will not regain its rightful priority among all the sciences. ${ }^{53}$

This minimalist weakness of scientific positivism quickly became the subject of harsh criticism not only from various parts of academic life, but also it was enough to start strong anti-positivist opposition. This opposition was able to carry out not only larger or smaller positivist criticism of thoughts, but was able to reach for the past maximalist views, restore them carefully and, with time, convert them into worldwide original concepts. At first, this was based on their own research on the broadly defined reality. But then, it referred to the studies, which were based on a criticism of the scientific method and the results obtained by the positivists. Finally, all that was abandoned and so some researchers began to jointly explore, exchange opinions, and even lead a scientific dialogue with other representatives of the non-positivist science, who as carefully as positivists, observed the transformations in civilization, which took place over the last centuries.

That is the reason why the modern philosophical trends of Western Europe have not died down. Instead, there has been a rebirth and development throughout the philosophical world. Thus, e.g., in Germany, Kantian thinking did not expire, it revived and a new methodology was presented by the once famous Kuno Fischer (1824-1907). While in the natural sciences, Kantian ideas were revived by the well-known Hermann Helmholtz (1821-1894). In that philosophy, the renaissance of Kantianism was given life by the memorable Otto Liebmann (1840-1912) or Friedrich Albert Lange (1828-1875). All of those German neo-Kantian philosophers not only effectively competed with the empiriocriticism of Richard Avenarius (1843-1896) and Ernest Mach

\footnotetext{
53 See a fundamental historical analysis, in Poland, by Morawiec (1994, p. 254) where you can find a professional literature of the subject.
} 
(1838-1916), but they were also able to dominate the German philosophy at the beginning of the 20th century, slowly giving way to the metaphysics of Wilhelm Wundt (1832-1920), Gustaw Teodor Fechner (1801-1887), Rudolf Hermann Lotze (1817-1881), or Eduard von Hartmann (1842-1906).

In France, by the end of the 19th century, philosophy was taught in schools according to Victor Cousin's (1792-1867) program that used to be very influential. However, with this kind of school spiritualistic-eclectic metaphysics quickly clashed in a duel, with both the French philosophical positivism and metaphysics of Charles Renouvier (1815-1903), Alfred Fouillèe (1838-1912), Jean-Marie Guyau (1854-1888), or Jules Lachelier (1832-1918).

It was thanks to Thomas Hill Green (1836-1882) that conservative English society ${ }^{54}$ heard, in 1874 , that they should at least reject native positivism and turn to the idealistic systems which derived from the previous epoch of Kant and Hegel. They also heard similar ideas from Ralph Wald Emerson (1803-1882), Francis Herbert Bradley (1846-1924), James Ward (1843-1925), and Josiah Royce (1855-1916). ${ }^{55}$

Even in Poland, in the peak development of positivism, there were some critical voices, as for example, a "real idealist" Henryk Struve ${ }^{56}$ (1840-1912) or a defender of the so-called hypothetical metaphysics Mscislaw Wartenberg $^{57}$ (1868-1938). They propagated that the philosophical minimalism, proposed mainly by native or foreign positivists, did not hold up to the criticism of human mind, which had, by nature, a maximalist attitude to knowledge about itself and the world around. ${ }^{58}$

Hence, it is not surprising that, at this time, on the stage of European thinking, there was a place for maximalistic understanding of the faith philosophy of, the today blessed cardinal John Henry Newman (1801-1890), the existential philosophy of Søren Kierkegaard (1813-1855), the intuitionism of Henri Bergson (1859-1941), the individualism of Max Stirner (1806-1856), the elitism of Thomas Carlyle (1795-1881), and for many others, more or less significant philosophers and their philosophical trends.

Finally, the revival of Christian thought (in maximalist view) happened as it had to, mainly through the revival of medieval scholasticism philosophy, which is familiar to us from the general history of philosophy, and is sometimes called the "neo-scholastic movement" or the shorter "neo-scholastic".

\footnotetext{
${ }^{54}$ This English attitude confirms the best an Anglo-Saxon historian of philosophy, Frederick Copleston, who thought that: "The excesses connected with the French Revolution produced in England a strong reaction which found notable expression in the reflections of Edmund Burke (1729-97), with their emphasis on social stability and tradition. But after the Napoleonic Wars at any rate the movement of radical reform was more easily able to make its influence felt. And in this movement utilitarianism possesses an undeniable historical importance" (Copleston, 1989, p. 9).

${ }_{55}$ More about Green's idealistic attitude, Emerson's transcendentalism, Bradley's idealism, Ward's pluralistic spiritualism, and Royce's philosophy can be found in Coplestona (1989, pp. 170-183 (Green); pp. 194-223 (Bradley); pp. $252-255$ (Ward); pp. 267-270 (Emerson); pp. 272-292 (Royce)). There, you can find a professional English and Polish literature of the subject.

56 According to Barbara Skarga (1919-2009), "Throughout the period of his activity Struve conducted disputes with the positivists. He referred to them, usually with a critical superiority, without taking into account any changes through which this current in Poland underwent. In 1891 in the article 'Positivism and critical problems of philosophy' he repeated his previous accusations. He was a proponent of the thesis that positivism is not a Polish tradition of thought, and referring to Śniadecki or Kołłataj as to the precursors is unfounded" (Borzym, Floryńska, Skarga, \& Walicki, 1983, p. 239). See also Borzym (1991, pp. 17-26).

57 According to Bronisław Dembowski (born 1927) Wartenberg, in his work Obrona metafizyki, tries to analyze and refute the most important accusations against metaphysics in the second half of the 19th century. These accusations arose mainly as a justified reaction against metaphysics of German idealism. Without taking into consideration the facts and without drawing any common conclusions, criticism of metaphysics came out from empiricism understood in the spirit of Hume (positivists), or from the assumptions of Kant's philosophy (neo-Kantianism). See Dembowski (1997, p. 79). See also Mazierski (1953, pp. 75-120).

${ }^{58}$ Cf. a joint publication edited by Jan Szmyda (2000, p. 442), entitled Wizerunki filozofów i humanistów polskich. Wiek XX.
} 
On one hand, all the civilizational changes of the time led the humanity to the final collapse of the centuries-old domination of philosophy in favor of mathematics and science, which is common to the present. On the other hand, they have contributed to the above-characterized scientific positivism. And finally, they led to the philosophical revival of the medieval scholasticism, which was forgotten for centuries.

The renewed scholasticism that was being experienced at the time is in its second, generally unquestioned in academic literature, scientific youth and has lasted to this present day. Neo-scholasticism today is entering its next phase of scientific development, where the ultimate finale is currently difficult to predict. Therefore, it still requires further philosophical clarification, comparative studies, a more systematic analysis, etc.. To which this chapter is just a kind of introduction or scientific monograph.

\section{Conclusion}

The aim of this article is to provide a synthetic description of all existing civilizational changes that caused in the last three centuries unprecedented, in the history of humankind, civilization leap. These transformations, however, still require more accurate characterization, including the field of sports and tourism, preferably in the form of a series of studies and treatises concerning all the fundamental civilization transformations. Further research of this kind would confirm or negate the thesis presented in this article that the humanity at that time went through, generally speaking, three phases of historical changes of the world. Moreover, such research would also show for what actually reason people moved from theoretical studies of "why" to practical action of "how" they can subdue the entire reality that surrounds us. This does not mean that scientific questions and answers like "why" or "where" everything goes are given up. The intent is rather to clarify the precedence of one positivist issue over the metaphysical one. Manifested precisely in the practical subdue not only the planet Earth, but the entire universe.

Therefore, we can and should do more research not only about the individual historical transformations, but also about the phenomenon of sudden civilizational leap of all the world transformations. Also, it is interesting to analyze in detail once again, genesis and development of the so-called European scientific positivism, whose origins date back to the 18th century and continues almost uninterruptedly until the end of the 20th century.

The author would like to discuss all these above mentioned issues in the next treatise, titled World's Civilizational Transformations and European Philosophical-Religious Transformations at the Turn of 19th and 20th Centuries.

\section{References}

Baker, J. N. L. (1931). A history of geographical discovery and exploration. London: G. G. Harrap and Company Limited. Barbour, I. G. (1976). Myths, models, and paradigms. A comparative study in science and religion. New York, NY: Harper \& Row Publishers.

Baturo, W. (Ed.). (2008). Katastrofy i zagrożenia we wspótczesnym świecie. Warsaw: Państwowe Wydawnictwo Naukowe.

Bazylow, L. (1981). Historia powszechna 1789-1918. Warsaw.

Blond, G. (1960). Grands navigateurs. Paris: Gautier-Languereau.

Bocheński, J. M. (1986). Ku filozoficznemu myśleniu: Wprowadzenie do podstawowych pojęć filozoficznych (Trans. Bernard Białecki). Warszawa.

Borzym, S. (1991). Filozofia polska 1900-1950. Wrocław - Warsaw - Cracow.

Borzym, S., Floryńska, H., Skarga, B., \& Walicki, A. (1983). Zarys dziejów filozofii polskiej 1815-1918. Warsaw.

Bronk, A., \& Majdański, S. (1992). Klasyczność filozofii klasycznej. RF. 39/40(1991/1992), z. 1, pp. 367-391.

Brown, J. R. (2001). The Oxford illustrated history of theatre. Oxford: Oxford University Press.

Brzeziński, T. (1988). Historia medycyny (pp. 15-16). Warsaw: Państwowy Zakład Wydawnictw Lekarskich. 
Bultmann, R. (1958). Jesus Christ and mythology. New York, NY: Charles Scribner's Sons.

Césaire, A. (1950). Discourse on colonialism. New York, NY: Monthly Review Press.

Chwalba, A. (2008). Historia Powszechna. Wiek XIX. Warsaw: Wydawnictwo Naukowe PWN.

Comte, A. (1864). Course on the positive philosophy (Vol. 2, p. 415). Paris.

Copleston, F. (1989). A history of philosophy (Vol. 8, p. 96). Warsaw: Bentham to Russell.

de Blinières, C. L. B. (1857). Exposition abrégée et populaire de la philosophie et de la religion positives (p. 83). Paris: Chamerot.

Dembowski, B. (1997). Spór o metafizykę i inne studia z historii filozofii polskiej. Włocławek.

Dziubiński, Z. (Ed.). (2006). Aksjologia turystyki. Warsaw: SALOS RP.

Dziubiński, Z. (Ed.). (2007). Drogi i bezdroża sportu i turystyki. Warsaw: SALOS RP.

Eliade, M. (1949). Traité d'Histoire des Religions. Paris: Payot.

Fanon, F. (1961). The wretched of the Earth. New York, NY: Grove Press.

Fernandez-Armesto, F. (2000). Civilizations: Culture, ambition, and the transformation of nature. New York, NY: Free Press.

Fukuyama, F. (1997). Trust: The social virtues and the creation of prosperity. Warsaw.

Fukuyama, F. (2000). The great disruption: Human nature and the reconstitution of social order. Warsaw: Wielki Wstrzą.

Furedi, F. (2006). Where have all the intellectuals gone? Confronting 21st century philistinism. Bloomsbury Academic.

Germain, S. (1833). Considérations générales sur l'état des sciences et des lettres aux différentes époques de leur culture. Paris.

Germain, S. (1896). Oeuvres philosophiques de Sophie Germain. Paris.

Gilson, E. (1968). The unity of philosophical experience. Warsaw.

Głombik, C. (2004). Ojciec Józef Bocheński. Drogi życia i myślenia filozoficznego. W stulecie urodzin uczonego. Gnome Katowice.

Griswold, C. L. (1999). Adam Smith and the virtues of enlightenment (pp. 17-21). Cambridge: Cambridge University Press.

Hayek, F. A. (1949). The intellectuals and socialism. Chicago: University of Chicago Press.

Hirschman, A. O. (1982). Rival interpretations of market society: Civilizing, destructive, or feeble? Journal of Economic Literature, 20(4), 1463-1484.

Hirszowicz, M. (2001). Pułapki zaangażowania, Intelektualiści w służbie komunizmu. Warsaw.

Hirszowicz, M. (2007). Stą, ale dokqd? Społeczeństwo u progu nowej ery. Warszawa.

Hołyst, B. (1983). Samobójstwo. Przypadek czy konieczność. Warsaw: Państwowe Wydawnictwo Naukowe.

Hołyst, B. (1991). Przywróceni życiu. Warsaw: Państwowe Wydawnictwo Naukowe.

Hołyst, B. (1998). Wiktymologia. Warsaw: Państwowe Wydawnictwo Naukowe.

Hołyst, B. (2000). Kryminalistyka (9th ed.). Warsaw: Państwowe Wydawnictwo Naukowe.

Hołyst, B. (2001). Kryminologia (6th ed.). Warsaw: Państwowe Wydawnictwo Naukowe.

Hołyst, B. (2002). Suicydologia. Warsaw: LexisNexis.

Janion, M. (2007). Niesamowita Stowiańszczyzna: Fantazmaty literatury. Kraków: Wydawnictwo Literackie.

Johnson, P. (1988). Intellectuals. London: Weidenfeld \& Nicolson.

Joint Publication. (2007). Wielkie biografie. Pisarze, kompozytorzy, artyści. Warsaw.

Joint Publication. (2007). Wielkie biografie. Przywódcy, reformatorzy, myśliciele. Warsaw.

Joint Publication. (2008). Wielkie biografie. Odkrywcy, wynalazcy, uczeni. Warsaw.

Kant, I. (1787). Krytyka czystego rozumu (Critique of pure reason).

Kramer, W. (1953). Die Entdeckung und Erforschung der Erde. Mit einem ABC der grossen Entdecker und Forscher. Leipzig: Brockhaus.

Levi-Strauss, C. (1958). Antropologie structurale. Paris: Plon.

Lilla, M. (2006). Lekkomyślny umyst. Intelektualiści w polityce. Warsaw.

Littré, E. (1864). August Comte et la philosophie positive (p. 107). Paris.

Łukasiewicz, J. (1906). Analiza i konstrukcja pojęcia przyczyny. Przeglạd Filozoficzny 6, z. 2/3, p. 59.

Malia, M. (2006). History's locomotives: Revolutions and the making of the modern world. New Haven, CT: Yale University Press.

Malinowski, B. (1990). Magic, science, and religion (Vol. 7). Warsaw.

Markiewicz, H. (1978). Positivism. Warsaw: Państwowe Wydawnictwo Naukowe.

Mazierski, S. (1953). Koncepcja metafizyki hipotetycznej u M. Wartenberga. "CT” 24 (1953), z. 1-4, pp. 75-120.

Michalski, S. (1898-1911). Poradnik dla samouków (Vol. 6). 
Miłosz, C. (1989). Zniewolony umyst. Kraków: Krajowa Agencja Wydawnicza.

Morawiec, E. (1994). Odkrycie metafizyki egzystencjalnej. Warsaw.

Morawiec, E. (1998). Podstawowe zagadnienia metafizyki klasycznej. Warsaw.

Mylik, M. (1997). Sophie Germain - zapomniana prekursorka pozytywizmu. In "Studia Philosophiae Christianae" (33/1).

Mylik, M. (2005). Stefan Pawlicki: Jeden z prekursorów nauki polskiej. Wydawnictwo: Uniwersytetu Kardynała Stefana Wyszyńskiego.

Mylik, M. (2006). Filozofia powstania, Wprowadzenie do problematyki powstania rzeczywistości w świetle generacjonizmu starożytnego a kreacjonizmu chrześcijańskiego. Skierniewice.

Pajewski, J. (1967). Historia powszechna 1871-1918 (p. 290). Warsaw: Państwowe Wydawnictwo Naukowe.

Parry, B., \& Sprinker, M. (1998). Delusions and discoveries: India in the British imagination, 1880-1930. London: Verso.

Pawlicki, S. (1884). O poczatkach chrześcijaństwa. Cracow.

Pawlicki, S. (1884/1885; 1885/1886; 1886/1887). Studia nad pozytywizmem. In "Przegląd Polski”, Cracow 1884/1885, Vol. 75, pp. 215-239, pp. 522-566; Vol. 76: 1884/1885, pp. 503-523; Vol. 77: 1885/1886, pp. 70-110; Vol. 78: 1885/1886, pp. 217-248, pp. 526-548; Vol. 79: 1885/1886, pp. 355-387; Vol. 81: 1886/1887.

Pawlicki, S. (1885). Studia nad pozytywizmem. Zofia Germain. In "Przegląd Polski”, Cracow 78/1885.

Pawlicki, S. (1888/1889). Historia pozytywizmu i szkót pokrewnych. Cracow: Course Book.

Pawlicki, S. (1905). Żywot i dzieła Ernesta Renana. In Przegląd Polski, Kraków 1893-1895.

Pawlicki, S. (2000). Historia filozofii nowożytnej. In M. Mylik (Ed.), Edition and proem. Warsaw.

Pieper, J. (1966). Verteidigungsrede für die Philosophie. Munich.

Pieper, J. (1985). W obronie filozofii (Trans. Piotr Waszczenko). Warszawa.

Said, E. (1978). Orientalism. New York, NY: Pantheon Books.

Seignobos, C. (1900). Dzieje polityczne Europy wspótczesnej. Rozwój stronnictw i form politycznych 1814-1899 (Trans. J. Stecki, Vols. 1-2). Warsaw.

Seria Wielkich Tematów. (2004). Idee i ideologie we współczesnym świecie. Warsaw: Państwowe Wydawnictwo Naukowe.

Seria Wielkich Tematów. (2008). Konflikty wspótczesnego świata. Warsaw: Państwowe Wydawnictwo Naukowe.

Spivak, G. C. (1990). The post-colonial critic: Interviews, strategies, dialogues. New York, NY: Routledge.

Spivak, G. C. (1999). A critique of postcolonial reason: Towards a history of the vanishing present. Cambridge, MA: Harvard University Press.

Sulimierski, F., \& Chlebowski, B. (1880-1914). Geographical dictionary of the Kingdom of Poland and other Slavic countries (Vol. 16). Poland.

Szafar, T. (1974). Odkrycie Afryki. Cztery tysiqclecia eksploracji Czarnego Ladu. Warsaw: Wydawnictwo Nasza Księgarnia.

Szmyda, J. (2000). Wizerunki filozofów i humanistów polskich. Wiek XX. Wydawnictwo Edukacyjne Cracow.

Tatarkiewicz, W. (1981). Historia filozofii (Vol. 3). Warsaw: PWN.

Toffler, A. (1980). The third wave. New York, NY: William Morrow Company, Inc..

Wróblewski, A. K. (2007). Historia fizyki. Od czasów najdawniejszych do współczesności. Warsaw: Wydawnictwo Naukowe PWN. 